\section{Determination of Strawberry Nutrient Optimum Ranges through Diagnosis and Recommendation Integrated System Analysis}

\author{
Thomas G. Bottoms ${ }^{1}$, Mark P. Bolda ${ }^{2}$, Mark L. Gaskell ${ }^{3}$, and \\ Timothy K. Hartz ${ }^{1,4}$
}

AdDitional INDEX wORDs. soil testing, tissue analysis, Fragaria $\times$ ananassa

SUMMARY. Diagnosis and recommendation integrated system (DRIS) leaf blade and petiole optimum nutrient ranges were developed through tissue sampling in $\mathbf{5 3}$ commercial strawberry (Fragaria $\times$ ananassa) fields in the coastal valleys of central California in 2010 and 2011 . All fields were in an annual production system using the day-neutral cultivar Albion. Leaf blades and petioles were sampled five times from early flowering through the fruit harvest period. Data on soil nutrient availability and grower fertilization practices were also collected. DRIS analysis was used to develop nutrient optimum ranges based on nutrient concentrations observed in nutritionally balanced, high-yield fields. Blade nitrogen $(\mathrm{N})$, phosphorus $(P)$, and potassium $(K)$ concentrations declined from the vegetative stage until the main harvest period, and stabilized thereafter. Blade calcium $(\mathrm{Ca})$, boron (B), and iron (Fe) increased over time while magnesium $(\mathrm{Mg})$, sulfur $(\mathrm{S})$, manganese $(\mathrm{Mn})$, zinc $(\mathrm{Zn})$, and copper $(\mathrm{Cu})$ decreased. The blade $\mathrm{N}$ optimum range was lower than previously published sufficiency ranges during the fruit harvest period, and the $\mathrm{Zn}$ optimum range was lower throughout the season. Other nutrients were in general agreement with previously established sufficiency ranges with the exception of $\mathrm{Ca}, \mathrm{Mn}$, and $\mathrm{Fe}$, which were higher. Petiole nitrate-nitrogen $\left(\mathrm{NO}_{3}-\mathrm{N}\right)$ was highly variable among high-yield fields, was not correlated with soil $\mathrm{NO}_{3}-\mathrm{N}$ at any growth stage, and was therefore of limited value as an indicator of crop $\mathrm{N}$ status. Comparison of soil nutrient availability with grower fertilization practices suggested that significant improvement in fertilizer management was possible.

$\mathrm{T}$ The majority of the U.S. strawberry crop is produced in California, predominately in the central coastal valleys. The annual production system uses day-neutral cultivars planted in the fall and typically grown for 9 to 12 months. Little fertility research has been conducted in this region in recent decades even as improvements in cultivars and production practices have dramatically raised fruit yields, which now commonly exceed 25 tons/acre. While there is a substantial body of recent research on strawberry $\mathrm{N}$ requirements from other production areas (Hochmuth et al., 1996; Kirschbaum et al., 2006; Miner et al., 1997; Santos and Chandler, 2009), these studies report on production systems with different environmental conditions,

${ }^{1}$ Department of Plant Sciences, University of California, Davis, CA 95616

${ }^{2}$ University of California Cooperative Extension, Watsonville, CA 95076

${ }^{3}$ University of California Cooperative Extension, San Luis Obispo, CA 93401

${ }^{4}$ Corresponding author. E-mail: tkhartz@ucdavis.edu. shorter production seasons and lower yield potential, and therefore may not be directly applicable. Relevant research on other nutrients in strawberry production is very limited.

Plant tissue nutrient testing is widely used in the California strawberry industry. However, the current California diagnostic guidelines (Ulrich et al., 1980) were developed more than 30 years ago and differ substantially for some nutrients from more recent sources (Campbell and Miner, 2000; Hochmuth and Albregts, 1994; Jones et al., 1991). With new cultivars and other advances in California strawberry production, a reevaluation of tissue nutrient diagnostic guidelines is warranted.

Foliar nutrient sufficiency guidelines for horticultural crops have typically been established through fertilizer rate studies conducted at a limited number of field sites, and usually evaluating only one or two nutrients. This approach may not adequately account for the effects of variability in field conditions, or the relative availability of other nutrients. Studies have shown that critical leaf $\mathrm{N}$ concentrations developed by such traditional fertilizer rate experiments can vary by location and year (Maier et al., 1990; Westerveld et al., 2003). Such confounding effects may partially explain the variability in published diagnostic guidelines.

An alternative approach to developing foliar nutrient concentration guidelines is DRIS analysis (Beaufils, 1973; Walworth and Sumner, 1987). In the DRIS approach, differences in foliar nutrient concentrations and nutrient ratios between high- and lowyielding fields are used to estimate the degree to which various nutrients may limit yield either by deficiency or excess. DRIS evaluation has been conducted on a number of horticultural crops (Angeles et al., 1993; Beverly, 1987; Caldwell et al., 1994; Hartz et al., 1998, 2007; Parent and Granger, 1989). DRIS has primarily been used as a diagnostic tool with which tissue nutrient concentrations from a specific field of interest could be compared with a set of established standards, or "norms," through the calculation of nutrient ratios and indices. Alternatively, the DRIS framework has been used to establish optimum leaf nutrient ranges (Hartz et al., 1998, 2007; Needham et al., 1990). The objective of this study was to develop DRIS leaf blade and petiole nutrient optimum

\begin{tabular}{llll}
\hline $\begin{array}{l}\text { Units } \\
\text { To convert U.S. to } \\
\text { SI, multiply by }\end{array}$ & U.S. unit & SI unit & $\begin{array}{l}\text { To convert SI to } \\
\text { U.S., multiply by }\end{array}$ \\
\hline 10 & $\%$ & $\mathrm{~g} \cdot \mathrm{kg}^{-1}$ & 0.1 \\
0.4047 & $\mathrm{acre}(\mathrm{s})$ & $\mathrm{ha}$ & 2.4711 \\
0.3048 & $\mathrm{ft}$ & $\mathrm{m}$ & 3.2808 \\
2.54 & inch $(\mathrm{es})$ & $\mathrm{cm}$ & 0.3937 \\
25.4 & inch $(\mathrm{es})$ & $\mathrm{mm}$ & 0.0394 \\
1.1209 & $\mathrm{lb} / \mathrm{acre}$ & $\mathrm{kg} \cdot \mathrm{ha}^{-1}$ & 0.8922 \\
1 & meq/100 g & $\mathrm{cmol} \cdot \mathrm{kg}^{-1}$ & 1 \\
1 & $\mathrm{ppm}$ & $\mathrm{mg} \cdot \mathrm{kg}^{-1}$ & 1 \\
2.2417 & ton/acre & $\mathrm{Mg} \cdot \mathrm{ha}^{-1}$ & 0.4461
\end{tabular}


ranges of broad applicability to the California strawberry industry.

\section{Material and methods}

A total of 53 commercial strawberry fields were sampled during the 2009-10 and 2010-11 production seasons. All were planted with the day-neutral cultivar Albion, the most widely used cultivar in this region. Plants were established in 4.0 to 5.2 -ft-wide, plastic-mulched beds in October or November at populations between 20,000 and 28,000 plants/ acre. All fields were drip irrigated. Fields were located in the WatsonvilleSalinas (lat $33^{\circ} \mathrm{N}$, long. $122^{\circ} \mathrm{W}$ ) and Santa Maria (lat. $37^{\circ} \mathrm{N}$, long. $122^{\circ} \mathrm{W}$ ) production districts along the central coast of California. The fields, ranging from $\approx 5$ to 20 acres, represented diverse soil characteristics and grower fertilization practices. To examine soil characteristics, composite soil samples (at least 12 cores, top 12 inch depth) were collected in each field between January and March and were air-dried and screened through $2-\mathrm{mm}$ mesh. Care was taken during soil sampling to avoid the bands of controlledrelease fertilizer (CRF) applied by most growers below the plant row before plant establishment. Soil pH was determined using saturated paste extracts (Rhoades, 1982). Total N and carbon $(\mathrm{C})$ were determined using a combustion analyzer (Thermo Finnigan Flash EA 1112; Thermo Fisher Scientific, Waltham, MA). Soil texture was quantified by the hydrometer method of Sheldrick and Wang (1993). Phosphorus availability was estimated by bicarbonate extraction (Olsen and Sommers, 1982). Soilexchangeable $\mathrm{K}, \mathrm{Ca}, \mathrm{Mg}$, and $\mathrm{Na}$ were measured by atomic emission spectrometry following ammonium acetate extraction (Thomas, 1982). DTPA-extractable soil $\mathrm{Zn}, \mathrm{Mn}, \mathrm{Fe}$, and $\mathrm{Cu}$ were determined by atomic absorption spectrometry (Lindsay and Norvell, 1978).

Whole leaf samples were collected five times in each field. Fields were sampled at different times in Santa Maria (mid-February through midAugust) and Watsonville-Salinas (midMarch through September) to ensure that the relative phenological stages were matched; Santa Maria is an earlier production district. In both districts, sampling stage 1 was early flowering, stage 2 was early fruit harvest, and stages 3-5 represented the main harvest period; with this cultivar fruit production was relatively consistent across stages $3-5$, and at a much higher level than at stage 2 . Within a given field, sampling was done on $\approx 5$ to 6-week intervals. At each stage, a composite sample of 30 whole, recently matured trifoliate leaves (petiole plus blade) were collected. Root zone soil samples (top 12 inches) were collected concurrently with each plant sampling, with at least 12 soil cores per field per sampling date combined to make a composite sample.

Leaves were rinsed in a $0.5 \%$ detergent solution and then in deionized water to minimize surface contamination. The petioles were removed from the leaf blades, and the tissues were oven-dried separately and ground to pass a $0.4-\mathrm{mm}$ screen. Total blade $\mathrm{N}$ was determined using a combustion analyzer (model FP-528; LECO Corp., St. Joseph, MI). All other blade nutrient analyses were conducted using inductively coupled plasma atomic emission spectrometry (ICP-AES) after microwave digestion with nitric acid and hydrogen peroxide (Sah and Miller, 1992). Petiole tissue was extracted in $2 \%$ acetic acid (Miller, 1998). Petiole $\mathrm{NO}_{3}-\mathrm{N}$ and phosphate-phosphorus $\left(\mathrm{PO}_{4}-\mathrm{P}\right)$ were determined using a flow injection analyzer (Lachat Instruments, Milwaukee, WI), while $\mathrm{K}$ was quantified by ICPAES. Ripe fruit samples were collected in all fields at stages 2 and 4 and analyzed as described for blade tissue. Soil $\mathrm{NO}_{3}-\mathrm{N}$ was determined in $2 \mathrm{~N}$ potassium chloride $(\mathrm{KCl})$ extracts by the spectrophotometric method of Doane and Horwath (2003).

Participating growers reported marketable fruit yield and all fertilizer applications at the end of each production season. Data were combined across production seasons, and fields were separated into high- and lowyield groups. High-yield fields were defined as those with $>30$ tons/acre of fruit by the end of August (Santa Maria) or by the end of September (Watsonville-Salinas). Low-yield fields were defined as those with $<27.5$ tons/ acre. These yield groups represented about the upper and lower third of the yield distribution of the monitored fields.

DRIS analysis was conducted following the method of Walworth and Sumner (1987). In brief, the mean and variance for three mathematical expressions relating each nutrient pair (e.g., $\mathrm{N} / \mathrm{P}, \mathrm{P} / \mathrm{N}, \mathrm{N} \times \mathrm{P}$ ) were calculated for both yield groups at each sampling stage. The expression that maximized the ratio [low-yield variance/high-yield variance] was selected as the DRIS norm for that nutrient pair. For each high-yield field at each growth stage, a DRIS index for each nutrient was calculated by comparing all expressions containing that nutrient (e.g., $\mathrm{N} / \mathrm{P}, \mathrm{N} \times \mathrm{K}, \mathrm{Ca} / \mathrm{N}$, etc.) with the corresponding DRIS norm, and summing the results. Following

Table 1. Range of soil characteristics [top 12 inches $(30.5 \mathrm{~cm})$ ] in 53 California strawberry fields.

\begin{tabular}{|c|c|c|c|}
\hline Characteristic & Unit $^{\mathrm{z}}$ & Mean & Range \\
\hline $\mathrm{pH}$ & & 6.9 & $5.9-7.5$ \\
\hline Total nitrogen ${ }^{y}$ & $\mathrm{~g} \cdot \mathrm{kg}^{-1}$ & 0.71 & $0.23-1.61$ \\
\hline Total carbon ${ }^{y}$ & $\mathrm{~g} \cdot \mathrm{kg}^{-1}$ & 7.3 & $2.2-15.0$ \\
\hline Sand & $\%$ & 64 & $26-95$ \\
\hline Silt & $\%$ & 21 & $1-45$ \\
\hline Clay & $\%$ & 15 & $4-47$ \\
\hline Exchangeable potassium $^{\mathrm{x}}$ & $\mathrm{cmol} \cdot \mathrm{kg}^{-1}$ & 0.49 & $0.10-1.09$ \\
\hline Exchangeable calcium $^{\mathrm{x}}$ & $\mathrm{cmol} \cdot \mathrm{kg}^{-1}$ & 7.1 & $2.0-22.2$ \\
\hline Exchangeable magnesium $^{\mathrm{x}}$ & $\mathrm{cmol} \cdot \mathrm{kg}^{-1}$ & 1.7 & $0.6-10.9$ \\
\hline Exchangeable sodium $^{\mathrm{x}}$ & $\mathrm{cmol} \cdot \mathrm{kg}^{-1}$ & 0.3 & $0.1-1.5$ \\
\hline Extractable phosphorus ${ }^{w}$ & $\mathrm{mg} \cdot \mathrm{kg}^{-1}$ & 82 & $27-191$ \\
\hline Extractable zinc ${ }^{\mathrm{v}}$ & $\mathrm{mg} \cdot \mathrm{kg}^{-1}$ & 3.3 & $0.7-9.8$ \\
\hline Extractable manganese $^{\mathrm{v}}$ & $\mathrm{mg} \cdot \mathrm{kg}^{-1}$ & 13.9 & $1.4-39.7$ \\
\hline Extractable iron ${ }^{\mathrm{v}}$ & $\mathrm{mg} \cdot \mathrm{kg}^{-1}$ & 23.2 & $7.8-65.0$ \\
\hline Extractable copper $^{v}$ & $\mathrm{mg} \cdot \mathrm{kg}^{-1}$ & 1.3 & $0.4-3.3$ \\
\hline $\begin{array}{l}{ }^{2} 1 \mathrm{~g} \cdot \mathrm{kg}^{-1}=0.1 \%, \mathrm{l} \mathrm{cmol} \cdot \mathrm{kg}^{-1}=1 \\
{ }^{y} \text { Combustion method. } \\
{ }^{x} \text { Ammonium acetate extraction. } \\
\text { "Bicarbonate extraction. } \\
\text { "DTPA extraction. }\end{array}$ & $\mathrm{mg} \cdot \mathrm{kg}^{-1}=1$ & & \\
\hline
\end{tabular}


the precedent of Beaufils (1973), a nutrient index within $1.33 \mathrm{SD}$ of the high-yield group's zero index value was considered to be balanced and sufficient for high-yield production; \pm 1.33 sD would theoretically encompass $\approx 80 \%$ of high-yield fields, assuming a normal distribution. High-yield fields were then evaluated for overall nutrient balance, defined as having $\mathrm{N}$, $\mathrm{P}$, and $\mathrm{K}$ indices within $1.33 \mathrm{SD}$ of the zero index value.

Using only the high-yield, nutritionally balanced fields, the linear regression relationship between each DRIS nutrient index and the respective blade nutrient concentration was calculated. For all the regressions that were significant at $P<0.05$, optimum blade nutrient concentration ranges were defined as the ranges corresponding to the zero value of the DRIS index, \pm 1.33 SD of that nutrient concentration in the balanced, high-yield fields. For nutrients for which the regression was not significant, the optimum range was defined simply as the mean nutrient concentration $\pm 1.33 \mathrm{SD}$ of the balanced, high-yield fields. Petiole optimum nutrient ranges were calculated as the sampling stage-specific mean concentration \pm 1.33 SD of the balanced, high-yield fields.

Regression analysis was performed using the data analysis package in Excel software (Microsoft, Redmond, WA). All other statistical analyses were conducted using SAS (version 9.1; SAS Institute, Cary, NC). Shapiro-Wilk tests for normality were employed on each nutrient at each growth stage using the UNIVARIATE procedure. Correlation analysis was performed using the CORR procedure.

\section{Results and discussion}

A wide range of soil characteristics were encountered in the monitored fields (Table 1). In general, soils had relatively low organic matter (means of 0.71 and $7.3 \mathrm{~g} \cdot \mathrm{kg}^{-1}$ total $\mathrm{N}$ and $\mathrm{C}$, respectively) and high $\mathrm{P}$ and $\mathrm{K}$ availability (means of $82 \mathrm{mg} \cdot \mathrm{kg}^{-1}$ and 0.49 $\mathrm{cmol} \cdot \mathrm{kg}^{-1}$, respectively). Soil $\mathrm{pH}$ ranged from 5.9 to 7.5 . Base exchange was dominated by $\mathrm{Ca}(74 \%$ of base exchange on average).

Median seasonal fertilizer application was 205,48 , and $145 \mathrm{lb} /$ acre $\mathrm{N}, \mathrm{P}$, and $\mathrm{K}$, respectively (Fig. 1). Fertilization varied widely among fields; seasonal application rates ranged from 118 to 424,11 to 136 , and 71 to
$370 \mathrm{lb} /$ acre $\mathrm{N}, \mathrm{P}$, and $\mathrm{K}$, respectively. Across fields, about half of the seasonal $\mathrm{N} / \mathrm{P} / \mathrm{K}$ application was in the form of preplant CRF, with the remainder fertigated using drip irrigation; many different fertilizers, and fertilizer blends, were used. Fruit yield was not correlated with the application rate of $\mathrm{N}, \mathrm{P}$, or $\mathrm{K}$.
Across all fields, blade N, P, and $K$ concentrations declined from stage 1 (early flowering) to stage 3 (main harvest period) and stabilized thereafter (Fig. 2). Petiole $\mathrm{PO}_{4}$-P showed a similar pattern, while petiole $\mathrm{NO}_{3}-\mathrm{N}$ and $\mathrm{K}$ declined throughout the season. Petiole nutrient concentrations

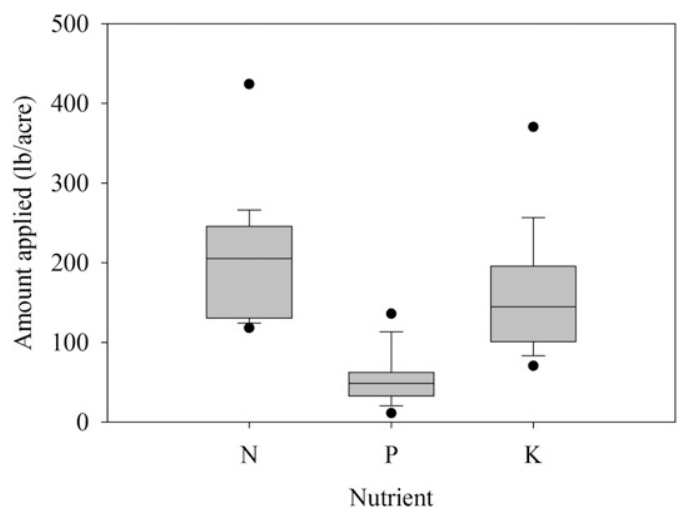

Fig. 1. Seasonal nitrogen $(\mathrm{N})$, phosphorus $(\mathrm{P})$, and potassium $(\mathrm{K})$ fertilizer application in 53 California strawberry fields. The shaded boxes enclose the first and third quartiles of fields, and the lines inside the boxes represent the median. The bars represent the 10th and 90th percentile, and the closed circles represent the range of observations; $1 \mathrm{lb} / \mathrm{acre}=0.8922 \mathrm{~kg} \cdot \mathrm{ha}^{-1}$.
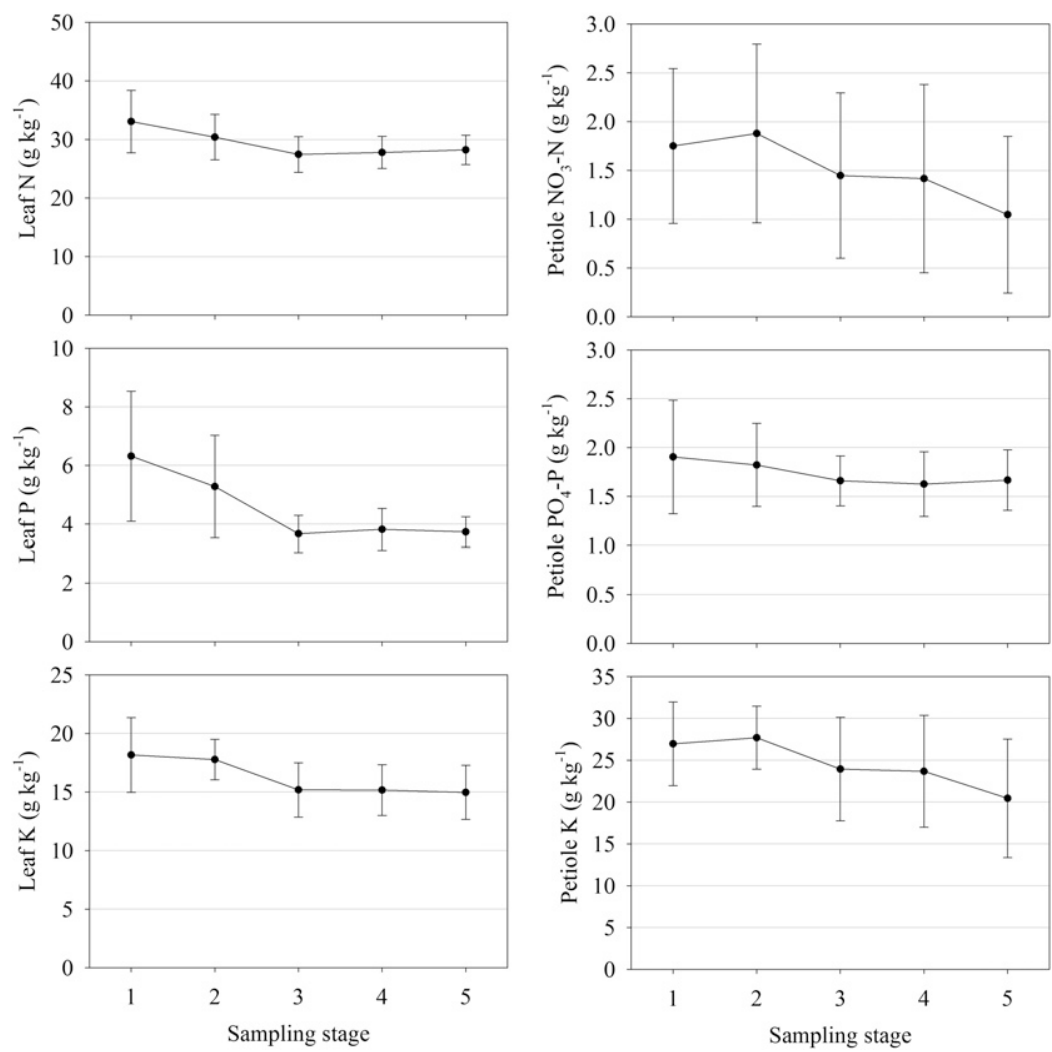

Fig. 2. Concentration of leaf blade nitrogen $(\mathrm{N})$, phosphorus $(\mathrm{P})$, and potassium $(\mathrm{K})$ and petiole nitrate-nitrogen $\left(\mathrm{NO}_{3}-\mathrm{N}\right)$, phosphate-phosphorus $\left(\mathrm{PO}_{4}-\mathrm{P}\right)$, and $\mathrm{K}$ in 53 California strawberry fields across the production season. Sampling stage 1 = early flowering, 2 = early harvest, and 3-5 = main harvest; bars indicate \pm 1 SD; $1 \mathrm{~g} \cdot \mathrm{kg}^{-1}=0.1 \%$. 
were more variable than blade concentrations. Decreasing blade N, P, and K concentrations were expected during fruiting as fruit constitute a substantial nutrient sink. Fruit nutrient concentrations declined over time, with $\mathrm{N}, \mathrm{P}$, and $\mathrm{K}$ averaging $14.8,3.8$, and $23.5 \mathrm{~g} \cdot \mathrm{kg}^{-1}$ dry weight, respectively, at stage 2 , and $13.6,3.2$, and $21.6 \mathrm{~g} \cdot \mathrm{kg}^{-1}$ at stage 4 . The decrease in fruit nutrient concentrations was likely due to greater fruit production at stage 4 compared with stage 2 . Across fields and growth stages, fruit contained $\approx 2.6,0.6$, and $4.2 \mathrm{lb} /$ ton fresh weight of $\mathrm{N}, \mathrm{P}$, and $\mathrm{K}$, respectively. These values were higher than those reported by others (Black et al., 2005; Tagliavini et al., 2004).

Blade concentrations of other nutrients showed an inconsistent pattern, with $\mathrm{Ca}, \mathrm{B}$, and $\mathrm{Fe}$ increasing and $\mathrm{S}, \mathrm{Mg}, \mathrm{Mn}, \mathrm{Zn}$, and $\mathrm{Cu}$ decreasing between stages 1 and 4 (Fig. 3 ). For all nutrients, both the pattern of blade concentration change over the season, and the range of values encountered, were similar to those reported for whole leaves in Spain by Dominguez et al. (2009). Conversely, Niskanen and Dris (2002) found lateseason whole leaf $\mathrm{N}, \mathrm{P}, \mathrm{Ca}$, and $\mathrm{Mg}$ in Finland to be much lower than the blade concentrations encountered in this study. Since petioles constitute $<10 \%$ of whole leaf dry weight, and petiole and blade concentrations of most elements do not differ radically, whole leaf and blade nutrient concentrations are quite comparable.

Correlations between initial soil nutrient availability and blade nutrient concentration were generally poor; only Mn showed a statistically significant correlation at all stages $[r$ varying from 0.45 to $0.71(P<0.01)]$. Niskanen and Dris (2002) also found soil nutrient availability to be a poor predictor of blade nutrient concentration. Inseason fertilizer application was an obvious confounding factor in this relationship in this study.

Mean marketable yields were 36 and 24 tons/acre in the high- and low-yield groups, respectively. Depending on the growth stage, between 12 and 14 high-yield fields were classified as nutritionally balanced for $\mathrm{N}, \mathrm{P}$, and K. Shapiro-Wilk analysis indicated that blade $\mathrm{N}, \mathrm{P}$, and $\mathrm{K}$ concentrations of high-yield, nutritionally balanced fields were normally distributed $(P<$ 0.05 ) at all sampling stages, confirming that the calculated nutrient optimum ranges would encompass values from $\approx 80 \%$ of high-yield fields. Blade concentrations of other nutrients were normally distributed at stages 1 and 2 , but one or more nutrients showed a skewed distribution at stages 3-5.

DRIS blade N, P, and K optimum ranges were compared with previously published sufficiency ranges (Table 2). Given the stability of blade nutrient concentrations throughout the main fruit harvest period (stages 3-5), only values for stage 4 are given. The DRIS blade $\mathrm{N}$ optimum range was lower than previously established sufficiency ranges during fruit harvest; only two high-yield fields met the $30 \mathrm{~g} \cdot \mathrm{kg}^{-1}$ sufficiency minimum suggested by Ulrich et al. (1980) and Campbell and Miner (2000). Conversely, the DRIS $\mathrm{P}$ and $\mathrm{K}$ ranges were higher than established standards, undoubtedly due to the high soil availability of these nutrients and high fertilization rates.

There was substantial variability among previously published references regarding $\mathrm{Ca}, \mathrm{Mg}$, $\mathrm{S}$, and micronutrient sufficiency (Table 3). DRIS optimum ranges for these nutrients generally fell within the established standards, with a few exceptions. Blade $\mathrm{Ca}, \mathrm{Mn}$, and $\mathrm{Fe}$ were higher, presumably due to high soil availability. Blade $\mathrm{Zn}$ was lower, with most high-yield fields failing to meet the $20 \mathrm{mg} \cdot \mathrm{kg}^{-1}$ standard of Jones et al. (1991), Hochmuth and Albregts (1994), and Ulrich et al (1980).

DRIS optimum petiole $\mathrm{NO}_{3}-\mathrm{N}$, $\mathrm{PO}_{4}-\mathrm{P}$, and $\mathrm{K}$ concentrations had broader ranges than for blade $\mathrm{N}, \mathrm{P}$, and $\mathrm{K}$ (Fig. 4). Petiole $\mathrm{NO}_{3}-\mathrm{N}$ was

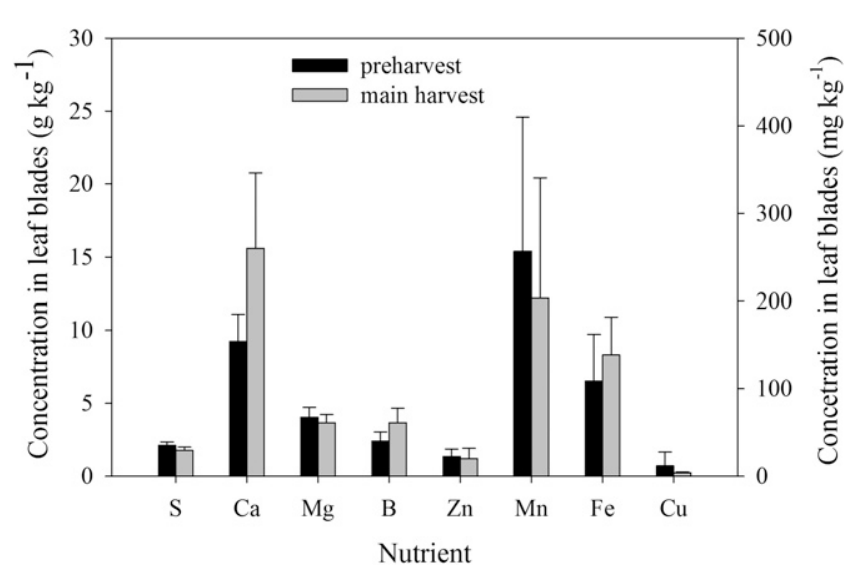

Fig. 3. Mean leaf blade calcium (Ca), magnesium (Mg), sulfur (S), and micronutrient concentrations at early flowering (stage 1 ) and main harvest (stage 4) for 53 California strawberry fields. Ca, $\mathrm{Mg}$, and $\mathrm{S}$ in $\mathrm{g} \cdot \mathrm{kg}^{-1}$; boron $(\mathrm{B})$, zinc $(\mathrm{Zn})$, manganese $(\mathrm{Mn})$, iron $(\mathrm{Fe})$; and copper $(\mathrm{Cu})$ in $\mathrm{mg} \cdot \mathrm{kg}^{-1}$; bars indicate $\pm 1 \mathrm{sD}$; $1 \mathrm{~g} \cdot \mathrm{kg}^{-1}=0.1 \%, 1 \mathrm{mg} \cdot \mathrm{kg}^{-1}=1 \mathrm{ppm}$.

Table 2. Comparison between diagnosis and recommendation integrated system (DRIS)-derived strawberry leaf blade nitrogen $(\mathrm{N})$, phosphorus $(\mathbf{P})$, and potassium $(\mathrm{K})$ optimum ranges and previously established sufficiency ranges.

\begin{tabular}{|c|c|c|c|c|}
\hline \multirow[b]{2}{*}{ Growth stage } & \multirow[b]{2}{*}{ Sufficiency range } & \multicolumn{3}{|c|}{ Optimum range $\left(\mathrm{g} \cdot \mathrm{kg}^{-1}\right)^{\mathrm{z}}$} \\
\hline & & $\mathbf{N}$ & $\mathbf{P}$ & $\mathbf{K}$ \\
\hline \multirow{3}{*}{$\begin{array}{l}\text { Early flowering } \\
\quad(\text { stage } 1)\end{array}$} & DRIS optimum & $31-38$ & $6-9$ & $18-22$ \\
\hline & Jones et al. $(1991)^{y}$ & $25-40$ & $2.5-10$ & $13-30$ \\
\hline & Ulrich et al. $(1980)^{\mathrm{x}, \mathrm{w}}$ & $30+$ & $1.5-13$ & $10-60$ \\
\hline \multirow{2}{*}{$\begin{array}{l}\text { Early harvest } \\
\quad \text { (stage } 2)\end{array}$} & DRIS optimum & $27-32$ & $3-5$ & $16-18$ \\
\hline & Hochmuth and Albregts $(1994)^{y}$ & $30-35$ & $2-4$ & $15-25$ \\
\hline \multirow{4}{*}{$\begin{array}{l}\text { Main harvest } \\
\quad \text { (stage } 4)\end{array}$} & DRIS optimum & $24-30$ & $3-4$ & $13-17$ \\
\hline & Hochmuth and Albregts $(1994)^{y}$ & $28-30$ & $2-4$ & $11-25$ \\
\hline & Campbell and Miner $(2000)^{\mathrm{y}}$ & $30-40$ & $2-4$ & $11-25$ \\
\hline & Ulrich et al. $(1980)^{\mathrm{x}, \mathrm{w}}$ & $30+$ & $1.5-13$ & $10-60$ \\
\hline
\end{tabular}

\footnotetext{
${ }^{\mathrm{z}} 1 \mathrm{~g} \cdot \mathrm{kg}^{-1}=0.1 \%$.
}

y Range based on whole leaf analysis.

${ }^{\mathrm{x}}$ Range based on leaf blade analysis.

"Growth stage not specified. 
Table 3. Comparison between diagnosis and recommendation integrated system (DRIS)-derived strawberry leaf blade calcium (Ca), magnesium $(\mathrm{Mg})$, sulfur $(\mathrm{S})$, boron $(\mathrm{B})$, zinc $(\mathrm{Zn})$, manganese $(\mathrm{Mn})$, iron $(\mathrm{Fe})$, and copper $(\mathrm{Cu})$ optimum ranges and previously established sufficiency ranges.

\begin{tabular}{|c|c|c|c|c|c|c|c|c|c|}
\hline \multirow[b]{2}{*}{ Growth stage } & \multirow[b]{2}{*}{ Sufficiency range } & \multicolumn{3}{|c|}{ Optimum range $\left(\mathrm{g} \cdot \mathrm{kg}^{-1}\right)^{\mathrm{z}}$} & \multicolumn{5}{|c|}{ Optimum range $\left(\mathrm{mg} \cdot \mathrm{kg}^{-1}\right)^{\mathrm{z}}$} \\
\hline & & $\mathrm{Ca}$ & $\mathrm{Mg}$ & $S$ & B & $\mathrm{Zn}$ & Mn & $\mathrm{Fe}$ & $\mathrm{Cu}$ \\
\hline \multirow{2}{*}{$\begin{array}{l}\text { Early flowering } \\
\text { (stage } 1)\end{array}$} & DRIS & $6-13$ & $3.3-5.5$ & $1.9-2.3$ & $31-45$ & $12-28$ & $74-615$ & $72-138$ & $3.3-5.8$ \\
\hline & Ulrich et al. $(1980)^{\mathrm{y}, \mathrm{x}}$ & $4-27$ & $3-7$ & $1.0+$ & $35-200$ & $20-50$ & $30-700$ & $50-3000$ & $3-30$ \\
\hline \multirow{2}{*}{$\begin{array}{l}\text { Early harvest } \\
\quad(\text { stage } 2)\end{array}$} & DRIS optimum & $9-13$ & $2.9-3.9$ & $1.6-2.3$ & $36-57$ & $11-20$ & $48-506$ & $81-143$ & $3.3-4.9$ \\
\hline & Hochmuth and Albregts $(1994)^{\mathrm{y}}$ & $4-15$ & $2.5-5$ & $2.5-8.0$ & $20-40$ & $20-40$ & $30-100$ & $50-100$ & $5-10$ \\
\hline \multirow{3}{*}{$\begin{array}{l}\text { Main harvest } \\
\text { (stage } 4)\end{array}$} & Hochmuth a & $4-15$ & $2-4$ & $2.5-8.0$ & $20-40$ & $20-40$ & $25-100$ & $50-100$ & $5-10$ \\
\hline & Campbell and Miner $(2000)^{\mathrm{y}}$ & $5-15$ & $2.5-4.5$ & $1.5-4.0$ & $25-50$ & $15-60$ & $30-300$ & $50-300$ & $3-15$ \\
\hline & Ulrich et al. $(1980)^{\mathrm{x}, \mathrm{w}}$ & $4-27$ & $3-7$ & $1.0+$ & $35-200$ & $20-50$ & $30-700$ & $50-3000$ & $3-30$ \\
\hline
\end{tabular}

${ }^{\mathrm{z}} \mathrm{lg} \cdot \mathrm{kg}^{-1}=0.1 \%, \mathrm{l} \mathrm{mg} \cdot \mathrm{kg}^{-1}=1 \mathrm{ppm}$.

${ }^{\mathrm{R}}$ Range based on whole leaf analysis.

"Range based on leaf blade analysis.

${ }^{w}$ Growth stage not specified.

particularly variable, with values during stages 4 and 5 ranging from $<0.1$ to $>1.7 \mathrm{~g} \cdot \mathrm{kg}^{-1}$. Depending on the growth stage, up to 5 of the balanced, high-yield fields had petiole $\mathrm{NO}_{3}-\mathrm{N}$ below the $0.5 \mathrm{~g} \cdot \mathrm{kg}^{-1}$ critical level suggested by Ulrich et al. (1980). Contrary to the contention of Lacroix and Cousin (1997), we did not find petiole $\mathrm{NO}_{3}-\mathrm{N}$ to reflect current soil $\mathrm{NO}_{3}-\mathrm{N}$ availability; there was no correlation between petiole $\mathrm{NO}_{3}-\mathrm{N}$ and soil $\mathrm{NO}_{3}-\mathrm{N}$ at any sampling stage. We concluded that petiole $\mathrm{NO}_{3}-\mathrm{N}$ provided minimal guidance regarding plant $\mathrm{N}$ status or soil $\mathrm{NO}_{3}-\mathrm{N}$ availability, and that maintaining petiole $\mathrm{NO}_{3}-\mathrm{N}$ throughout the fruit harvest season at the level suggested by either Ulrich et al. (1980) for dry tissue or Hochmuth and Albregts (1994) for petiole sap was not necessary for highyield production.

The field survey approach to developing DRIS tissue optimum ranges has both strengths and weaknesses. An advantage was that collecting data from numerous fields selected to represent a wide range of soil characteristics, environmental conditions, and grower fertilization practices ensured that the optimum ranges developed have broad applicability to the regional industry. A limitation of this approach was that without including fields clearly deficient in the various nutrients, the resulting optimum ranges were likely to be higher than required to maximize yield. This restricts the application of the DRIS optimum ranges to confirming that an observed blade nutrient concentration
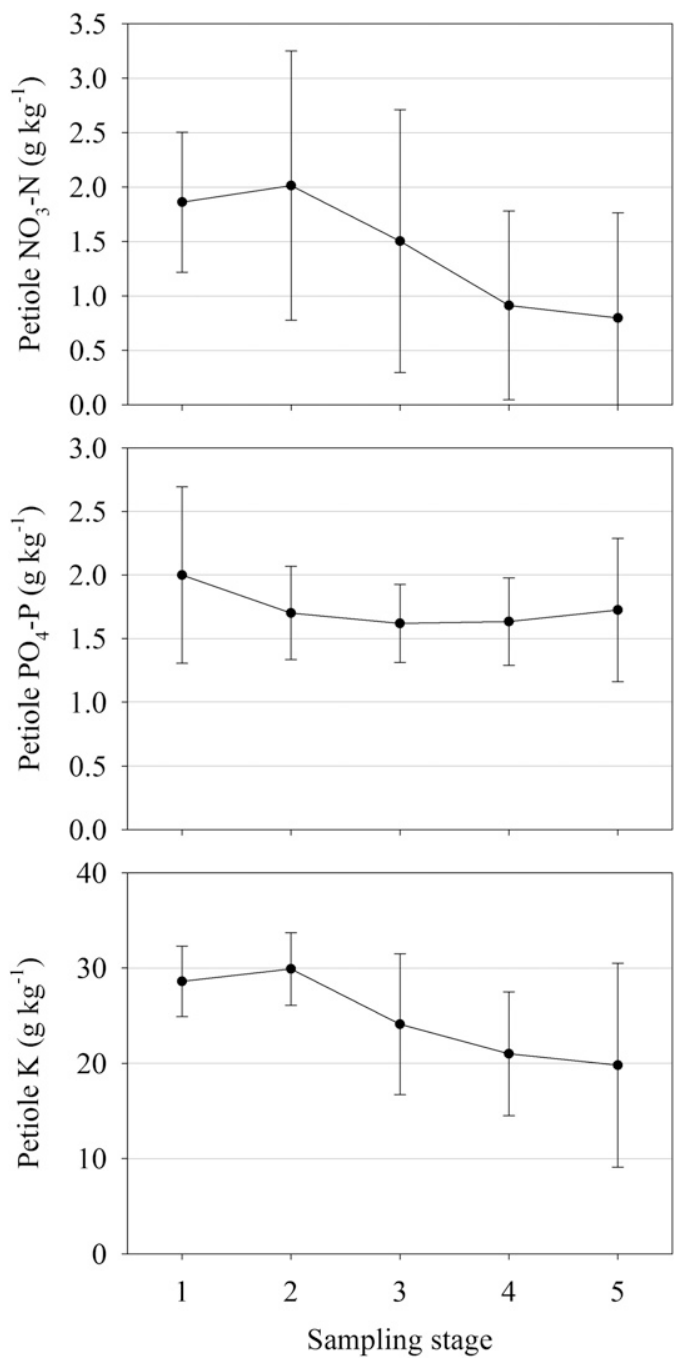

Fig. 4. Diagnosis and recommendation integrated system (DRIS) optimum strawberry petiole nitrate-nitrogen $\left(\mathrm{NO}_{3}-\mathrm{N}\right)$, phosphate-phosphorus $\left(\mathrm{PO}_{4}-\mathrm{P}\right)$, and potassium $(\mathrm{K})$ ranges across the production season. Sampling stage 1 = early flowering, 2 = early harvest, and 3-5 = main harvest; bars indicate \pm 1 SD about the mean of nutritionally balanced, high-yield fields; $1 \mathrm{~g} \cdot \mathrm{kg}^{-1}=0.1 \%$. 

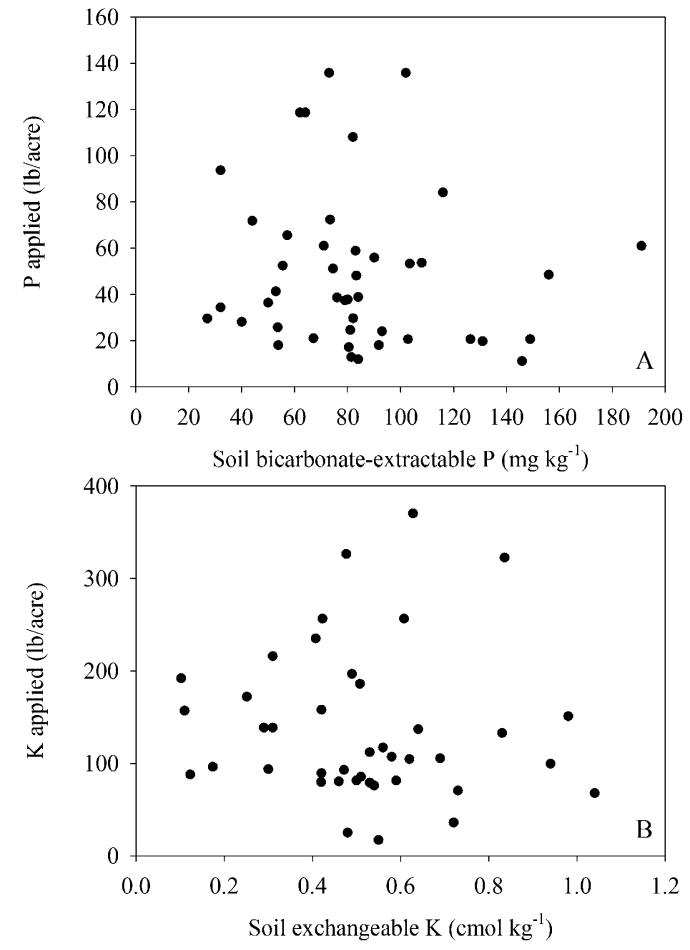

Fig. 5. Relationship between grower fertilizer application to strawberry and soil test phosphorus (P) and potassium (K); $1 \mathrm{mg} \cdot \mathrm{kg}^{-1}=1 \mathrm{ppm}, 1 \mathrm{cmol} \cdot \mathrm{kg}^{-1}=1 \mathrm{meq} / 100 \mathrm{~g}$, $1 \mathrm{lb} /$ acre $=0.8922 \mathrm{~kg} \cdot \mathrm{ha}^{-1}$.

is sufficient for high-yield production; one cannot necessarily infer that a value below the range is yield limiting.

This study also highlighted the importance of applying tissue nutrient standards that were developed under similar soil and environmental conditions. The blade nutrient concentrations found were similar to whole leaf concentrations reported from Spain (Dominguez et al., 2009), a semiarid, Mediterranean climate similar to California. Conversely, whole leaf nutrient concentrations reported from Finland (Niskanen and Dris, 2002) were quite different. Hochmuth and Albregts (1994), working in Florida, reported whole leaf Ca sufficiency to be as low as $4 \mathrm{~g} \cdot \mathrm{kg}^{-1}$; in this study the mean value observed after the initiation of harvest was more than three times that concentration, with $7.7 \mathrm{~g} \cdot \mathrm{kg}^{-1}$ the lowest value observed. It should also be noted that blade nutrient concentrations of shortday cultivars may be different from those observed in this study.

Beyond the development of tissue nutrient optimum ranges, this field survey also allowed evaluation of current nutrient management practices. Fertilization rates were widely variable.
$\mathrm{P}$ and $\mathrm{K}$ application rates were apparently unrelated to soil nutrient status (Fig. 5). Phosphorus management was particularly inefficient because the majority of fields had soil $P>60 \mathrm{mg} \cdot \mathrm{kg}^{-1}$, and therefore were unlikely to be responsive to P application (Ludwick, 2002; Johnstone et al., 2005). Preplant CRF application was a standard grower practice to ensure $\mathrm{N}$ availability through the winter, when heavy rain may occur. The CRF formulations currently favored by growers all contain significant quantities of $\mathrm{P}$ and $\mathrm{K}$; in fields of high $\mathrm{P}$ and $\mathrm{K}$ availability, switching to a CRF containing only $\mathrm{N}$ would be more efficient.

The wide range of seasonal $\mathrm{N}$ applications (118-424 lb/acre), and the fact that $\mathrm{N}$ application was not correlated with fruit yield, suggested that substantial improvement in $\mathrm{N}$ management was possible. Strawberry yields in annual production systems have been reported to be maximized by no more than $120 \mathrm{lb} /$ acre $\mathrm{N}$ in Florida (Hochmuth et al., 1996) and North Carolina (Miner et al., 1997), or $140 \mathrm{lb} /$ acre $\mathrm{N}$ in Argentina (Kirschbaum et al., 2006). These sources reported fruit yields between $\approx 12$ and 18 tons/acre, so higher seasonal $\mathrm{N}$ rates may be justified in California, given the much higher crop productivity. However, since fruit $\mathrm{N}$ content averaged only $2.6 \mathrm{lb} / \mathrm{ton}$, the $\mathrm{N}$ use efficiency of seasonal $\mathrm{N}$ rates in excess of the median observed in this study (205 lb N/acre) was undoubtedly low.

In summary, DRIS optimum blade and petiole nutrient ranges were developed for annual strawberry production in California. Blade optimum ranges were in general agreement with previously published sufficiency ranges, but were lower for $\mathrm{N}$ and $\mathrm{Zn}$ during the fruit harvest period. Petiole $\mathrm{NO}_{3}-\mathrm{N}$ concentration was highly variable, unrelated to concurrently measured soil $\mathrm{NO}_{3}-\mathrm{N}$, and therefore of limited utility. Substantial improvement of current industry fertilizer management appeared to be possible.

\section{Literature cited}

Angeles, D.E., M.E. Sumner, and E. Lahav. 1993. Preliminary DRIS norms for banana. J. Plant Nutr. 16:10591070 .

Beaufils, E.R. 1973. Diagnosis and recommendation integrated system (DRIS). Soil Sci. Bul. 1, Univ. Natal, Natal, South Africa.

Beverly, R.B. 1987. Modified DRIS method for simplified nutrient diagnosis of Valencia oranges. J. Plant Nutr. 10: 1401-1408.

Black, B.L., S.C. Hokanson, and K.S. Lewers. 2005. Fruit nitrogen content of sixteen strawberry genotypes grown in an advanced matted row production system. HortScience 40:1190-1193.

Caldwell, J.O., M.E. Sumner, and C.S. Vavrina. 1994. Development and testing of preliminary foliar DRIS norms for onions. HortScience 29:1501-1504.

Campbell, C.R. and G.S. Miner. 2000. Strawberry, annual hill culture, p. 111112. In: C.R. Campbell (ed.). Reference sufficiency ranges for plant analysis in the southern region of the United States. Southern Coop. Ser. Bul. 394.

Doane, T.A. and W.R. Horwath. 2003. Spectrophotometric determination of nitrate with a single reagent. Anal. Lett. 36:2713-2722.

Dominguez, A., E. Martinez, A. Trigo, D. Alonso, R. Garcia, R. Sanchez, R. Ghorbel, and J. Tomas. 2009. Seasonal changes in leaf mineral content may affect foliar diagnostic in strawberry. Acta Hort. 842: 147-150.

Hartz, T.K., P.R. Johnstone, E. Williams, and R.F. Smith. 2007. Establishing lettuce 
leaf nutrient optimum ranges through DRIS analysis. HortScience 42:143-146.

Hartz, T.K., E.M. Miyao, and J.G. Valencia. 1998. DRIS evaluation of the nutritional status of processing tomato. HortScience 33:830-832.

Hochmuth, G. and E. Albregts. 1994. Fertilization of strawberries in Florida. Univ. Florida Coop. Ext. Circ. 1141.

Hochmuth, G.J., E.E. Albregts, C.C. Chandler, J. Cornell, and J. Harrison. 1996. Nitrogen fertigation requirements of drip-irrigated strawberries. J. Amer. Soc. Hort. Sci. 121:660-665.

Johnstone, P.R., T.K. Hartz, M.D. Cahn, and M.R. Johnstone. 2005. Lettuce response to phosphorus fertilization in high phosphorus soils. HortScience 40:14991503.

Jones, J.B., B. Wolf, and H.A. Mills. 1991. Plant analysis handbook. MicroMacro Publ., Athens, GA.

Kirschbaum, D.S., A.M. Borquez, S.L. Quipildor, M. Correa, H. Magen, and P. Imas. 2006. Nitrogen requirements of drip irrigated strawberries grown in subtropical environments. Acta Hort. 708: 93-96.

Lacroix, C.R. and I. Cousin. 1997. Petiolar sap nitrate as a guide in the fertilization of strawberry. Acta Hort. 439: $753-762$.

Lindsay, W.L. and W.A. Norvell. 1978. Development of a DTPA soil test for zinc, iron, manganese and copper. Soil Sci. Soc. Amer. J. 42:421-428.

Ludwick, A.E. (ed.). 2002. Western fertilizer handbook. 9th ed. Interstate Publishers, Danville, IL.
Maier, N.A., A.P. Dahlenberg, and T.K. Twigden. 1990. Assessment of the nitrogen status of onions (Allium cepa) cv. Cream Gold by plant analysis. Austral. J. Exp. Agr. 30:853-859.

Miller, R.O. 1998. Extractable chloride, nitrate, orthophosphate, and sulfate-sulfur in plant tissue: $2 \%$ acetic acid extraction, p. 115-118. In: Y.P. Kalra (ed.). Handbook of reference methods for plant analysis. CRC Press, Boca Raton, FL.

Miner, G.S., E.B. Poling, D.E. Carroll, L.A. Nelson, and C.R. Campbell. 1997. Influence of fall nitrogen and spring nitrogen-potassium applications on yield and fruit quality of 'Chandler' strawberry. J. Amer. Soc. Hort. Sci. 122:290-295.

Niskanen, R. and R. Dris. 2002. Nutritional status of strawberry fields. Acta Hort. 567:439-442.

Needham, T.D., J.A. Burger, and R.G. Oderwald. 1990. Relationship between diagnosis and recommendation integrated system (DRIS) optima and foliar nutrient critical levels. Soil Sci. Soc. Amer. J. 54:883-886.

Olsen, S.R. and L.E. Sommers. 1982. Phosphorus, p. 403-430. In: A.L. Page, R.H. Miller, and D.R. Keeney (eds.). Methods of soil analysis: Part 2 Chemical and microbiological properties. Monogr. No. 9. Amer. Soc. Agron. Madison, WI.

Parent, L.E. and R.L. Granger. 1989. Derivation of DRIS norms from a highdensity apple orchard established in the Quebec Appalachian Mountains. J. Amer. Soc. Hort. Sci. 114:915-919.

Rhoades, J.D. 1982. Soluble salts, p. 167179. In: A.L. Page, R.H. Miller, and D.R. Keeney (eds.). Methods of soil analysis: Part 2 Chemical and microbiological properties. Monogr. No. 9. Amer. Soc. Agron. Madison, WI.

Sah, R.N. and R.O. Miller. 1992. Spontaneous reaction for acid dissolution of biological tissues in closed vessels. Anal. Chem. 64:230-233.

Santos, B.M. and C.K. Chandler. 2009. Influence of nitrogen fertilization rates on the performance of strawberry cultivars. Intl. J. Fruit Sci. 9:126-135.

Sheldrick, B.H. and C. Wang. 1993. Particle size distribution, p. 499-511. In: M.R. Carter (ed.). Soil sampling and methods of analysis. Can. Soc. Soil Sci., Lewis Publishers, Ann Arbor, MI.

Tagliavini, M., E. Baldi, R. Nestby, C. Raynal-Lacroix, P. Lieten, T. Salo, D. Pivot, P.L. Lucchi, G. Baruzzi, and W. Faedi. 2004. Uptake and partitioning of major nutrients by strawberry plants. Acta Hort. 649:197-200.

Thomas, G.W. 1982. Exchangeable cations, p. 159-165. In: A.L. Page, R.H. Miller, and D.R. Keeney (eds.). Methods of soil analysis: Part 2 Chemical and microbiological properties. Monogr. No. 9. Amer. Soc. Agron. Madison, WI.

Ulrich, A., M.A.E. Mostafa, and W.W. Allen. 1980. Strawberry deficiency symptoms. A visual and plant analysis guide to fertilization. Univ. California Bul. 4098.

Walworth, J.L. and M.E. Sumner. 1987. The diagnosis and recommendation integrated system (DRIS). Adv. Soil Sci. 6: 149-188.

Westerveld, S.M., A.W. McKeown, C.D. Scott-Dupree, and M.R. McDonald. 2003. How well do critical nitrogen concentrations work for cabbage, carrot and onion crops? HortScience 38:11221128. 